\title{
Correction to: Transient expression of human serum albumin (HSA) in tobaccoleaves
}

\author{
Behnam Sedaghati $^{1,2} \cdot$ Raheem Haddad $^{1}$ (D) Mojgan Bandehpour ${ }^{2}$
}

Published online: 7 September 2020

(c) Springer Nature B.V. 2020

\section{Correction to: \\ Molecular Biology Reports (2020) 47:5487-5495 \\ https://doi.org/10.1007/s11033-020-05640-y}

The article 'Transient expression of human serum albumin (HSA) in tobacco leaves' written by Behnam Sedaghati, Raheem Haddad, and Mojgan Bandehpour, was originally published online on 8th July 2020 with Open Access under a Creative Commons Attribution (CC BY) license 4.0. With the authors' decision to cancel Open Access the copyright of the article changed on 21st August 2020 to @ Springer Nature B.V. 2020 with all rights reserved. The original article has been corrected.

Publisher's Note Springer Nature remains neutral with regard to jurisdictional claims in published maps and institutional affiliations.

The original article can be found online at https://doi.org/10.1007/ s11033-020-05640-y.

Raheem Haddad

r.haddad@eng.ikiu.ac.ir

1 Department of Biotechnology, Faculty of Agriculture and Natural Resources, Imam Khomeini International University, Qazvin, Iran

2 Cellular and Molecular Biology Research Center, Shahid Beheshti University of Medical Sciences, Tehran, Iran 